
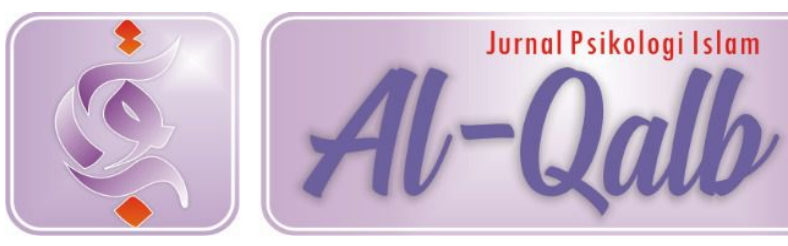

EISSN : 2686-326X

ISSN : 2085-8647

https://ejournal.uinib.ac.id/jurnal/index.php/alqalb/index

\title{
Hubungan Kebersyukuran Dengan Perilaku Prososial Pada Mahasiswa
}

Received: $20^{\text {th }}$ September 2019; Revised: 08 ${ }^{\text {th }}$ October 2019; Accepted: $24^{\text {th }}$ October 2019

\author{
Wildatul Husna \\ UIN Imam Bonjol Padang \\ Email: hwildatul7@gmaill.com \\ Reza Fahmi \\ UIN Imam Bonjol Padang \\ Email: rezafahmi@uinib.ac.id \\ Rizal Kurniawan \\ UIN Imam Bonjol Padang
}

\begin{abstract}
ABSTRAK. Penelitian ini dilatarbelakangi dengan hasil data awal yang peneliti temukan di lapangan bahwa masih banyak mahasiswa yang memiliki perilaku prososial rendah. Mereka tidak mau terlibat dengan masalah orang lain, tidak mau menolong, serta memiliki egosentrisme yang tinggi. Tujuan dari penelitian ini adalah untuk mengetahui kategori kebersyukuran, kategori perilaku prososial, dan hubungan kebersyukuran dengan perilaku prsososial mahasiswa prodi Ilmu Perpustakaan UIN Imam Bonjol Padang. Metode penelitian yang digunakan adalah metode penelitian kuantitatif dengan teknik korelasi. Variabel bebas dalam penelitian ini adalah kebersyukuran dan variabel terikat adalah perilaku prososial. Populasi dalam penelitian ini adalah mahasiswa prodi Ilmu Perpustakaan UIN Imam Bonjol Padang berjumlah 358 Mahasiswa dengan sampel penelitian berjumlah 189 mahasiswa. Penarikan sampel penelitian dengan menggunakan proportionate stratified random. Teknik pengumpulan data yang digunakan dalam penelitian ini adalah skala psikologi, yang berpedoman pada skala model Likert yang dimodifikasi. Penelitian ini menggunakan dua skala sebagai alat ukur yaitu skala kebersyukuran dan skala perilaku prososial. Hasil korelasi menunjukkan adanya hubungan positif antara kebersyukuran dengan perilaku prososial Nilai koefisien korelasi sebesar 0,486 yang berarah positif. Hasil penelitian menunjukkan bahwa $56,6 \%$ mahasiswa memiliki kebersyukuran yang tinggi dan sebanyak $52,4 \%$ mahasiswa menunjukkan perilaku prososial yang tinggi.
\end{abstract}

Kata Kunci: Kebersyukuran, Perilaku Prososial

\section{PENDAHULUAN}

Globalisasi memicu munculnya berbagai kemajuan dalam setiap bidang kehidupan. Banyak perubahan yang terjadi dalam berbagai bidang kehidupan manusia sebagai akibat dari proses globalisasi. Tarmudji (dalam Renata dan Parmitasari, 2016: 25) menyatakan perubahan-perubahan yang terjadi itu tidak hanya memberi dampak positif bagi kesejahteraan manusia tetapi juga menimbulkan dampak negatif. Akibatnya, bukanlah hal yang aneh bila nilai-nilai pengabdian, kesetiakawanan, dan tolong menolong mengalami penurunan.

Perilaku tolong-menolong serta sikap kooperatif atau kerja sama perlu dikembangkan manusia. Karena manusia bukan hanya makhluk individual namun juga makhluk sosial. Artinya, manusia selalu mengalami ketergantungan anatara individu yang satu dengan individu yang lainnya. Oleh karenanya, manusia tidak dapat memutuskan hubungan dengan sesamanya atau hidup dalam kesendirian dalam rangka 
mempertahankan kelangsungan hidupnya. Perilaku tolong-menolong disebut juga dengan perilaku prososial.

Perilaku prososial didasari dukungan nilai dan norma yang dianut individu. Perilaku prososial merupakan bagian dari kehidupan sehari-hari. Menurut Sears, Freedman, \& Peplau (2001: 47) perilaku prososial adalah segala bentuk tindakan yang dilakukan atau direncanakan untuk menolong orag lain, tanpa mempedulikan motif-motif si penolong.

Fenomena perilaku prososial dapat terjadi pada setiap lapisan masyarakat, tak terkecuali mahasiswa. Kamus Besar Bahasa Indonesia menyatakan bahwa mahasiswa adalah individu yang belajar di perguruan tinggi. Mahasiswa secara harafiah adalah orang yang belajar di perguruan tinggi, entah di universitas, institut atau akademi. Mahasiswa diharapkan telah mencapai kematangan moral. Individu yang telah mencapai kematangan moral tidak saja menghindari berbagai perilaku negatif, tetapi juga dapat memotivasi untuk berperilaku positif seperti dapat bekerjasama, empati, peduli, toleransi, termasuk berperilaku prososial.

Mahasiswa tentu pernah mengalami persoalan yang membutuhkan bantuan orang lain untuk keluar dari persoalannya. Terlebih sebagai kaum intelektual, mahasiswa dituntut dapat responsive terhadap permasalahan-permasalahan yang dihadapi masyarakat. Melalui keilmuan yang dikuasai, mahasiswa diharapkan tergugah kepeduliannya untuk mencermati permasalahan dan mengupayakan solusi yang menguntungkan masyarakat (Cahyono, 2016: 116).

Dalam Yulianti (2017) perilaku prososial yang bermasalah pada diri seorang individu dapat menyebabkan semakin rendahnya sikap peduli pada orang lain yang nantinya dapat mengakibatkan mereka tumbuh menjadi orang-orang yang memiliki sifat individual yang tinggi dan tidak suka menolong tanpa pamrih. Oleh karena itu, perlu ditanamkan dalam diri setiap orang, khususnya untuk para mahasiswa, yang merupakan bagian dari anggota masyarakat. Sehingga mahasiswa perlu dipersiapkan agar mampu berkiprah dalam memberikan pelayanan kepada anggota masyarakat. Oleh sebab itu, mahasiswa perlu memahami norma-norma dan nilai budaya karena sebagai anggota masyarakat mereka selalu dituntuk memiliki tanggung jawab dalam membantu, berbagi, dan memberikan sumbangan untuk mengurangi kesulitan orang lain. Selain itu, perilaku prososial penting untuk menjaga kelangsungan kehidupan antar sesama manusia. Dengan melakukan tindakan prososial maka sudah dapat membantu dan meringankan beban orang yang membutuhkan pertolongan.

$$
\text { Adapun faktor-faktor yang }
$$

mempengaruhi perilaku prososial antara lain adalah karakteristik situasi, karakteristik penolong, serta karakteristik orang yang membutuhkan pertolongan. Faktor karakteristik penolong yang mendorong individu untuk berperilaku prososial adalah faktor kepribadian, suasana hati, rasa bersalah serta distres diri dan rasa empatik (Sears, dkk, 2001: 61-69).

Menurut Chaplin (2006: 309) suasana hati adalah satu emosi yang lemah, lembut, biasanya transitoris (tidak berlangsung lama) sifatnya. Orang lebih terdorong untuk memberikan bantuan bila berada dalam suasana hati yang baik. Hasil penelitian terkait suasana hati yang mempengaruhi perilaku prososial sama sekali belum konsisten. Suasana hati yang buruk dapat membuat individu memusatkan perhatian pada dirinya sendiri. Di lain pihak, menolong orang bisa membuat individu merasa lebih baik (Sears, dkk, 2001: 63).

$$
\text { Syukur adalah keadaan yang }
$$
menyenangkan dan berhubungan dengan emosi positif. Syukur adalah memuji Dzat yang memberi kenikmatan yakni Allah SWT atas limpahan kebaikanNya yang telah dianugrahkan kepada kita. Syukur itu berkaitan dengan hati, lisan dan anggota badan (Ubaid, 2014:171). Hati yang bersyukur memperkuat dan memantapkan kebaikan yang ada, dan akan menghasilkan kebaikan yang belum ada. Orang awam 
hanya bersyukur apabila memperoleh rezeki material. Orang yang telah mengalami pencerahan batin selalu bersyukur baik ketika memperoleh nikmat atau tidak. Orang-orang yang telah memperoleh nur ilahi tidak mempedulikan nikmat maupun penderitaan, karena mereka melihat karunia dan rahmat Allah di balik semua penampakan dan pengalaman.

Kemudian Allah SWT juga menjelaskan bahwa kebersyukuran harus dinampakkan oleh manusia, karena jika manusia merasa tidak bersyukur maka berarti dia telah mengingkari dan tidak mengimani siapa pemberi nikmat-nikmat itu. Dan menampakkan syukur adalah dengan cara melakukan kebajikan yang dalam istilah psikologi sosial dikenal dengan perilaku prososial. Perilaku prososial ini terdapat dalam QS. Al-Maidah (5): 2

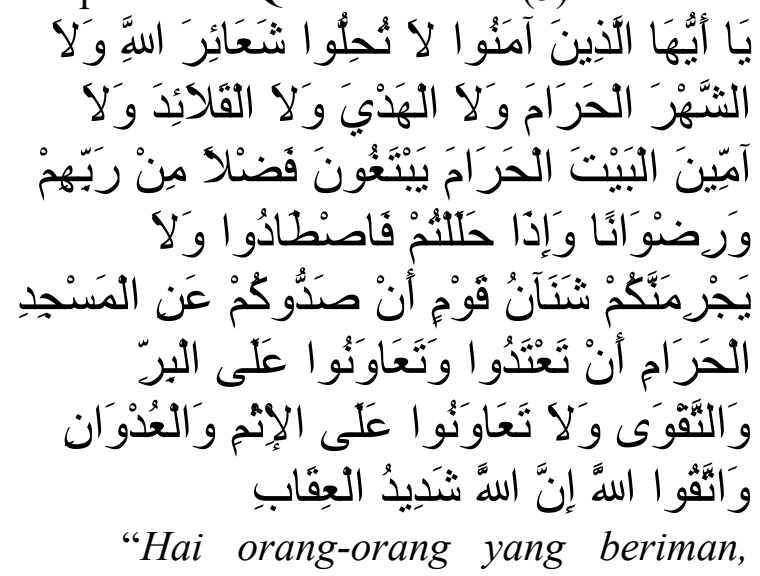

janganlah kamu melanggar syiar-syiar Allah, dan jangan melanggar kehormatan bulan-bulan

haram,

jangan (mengganggu) binatang-binatang hadya dan binatang-binatang galaid, dan jangan (pula) mengganggu orang-orang yang mengunjungi Baitullah sedang mereka mencari karunia dan keridaan dari Tuhannya; dan apabila kalian telah menyelesaikan ibadah haji, maka bolehlah berburu. Dan jangan sekali-kali kebencian (kalian) kepada sesuatu kaum karena mereka menghalang-halangi kalian dari Mesjidil Haram, mendorong kalian berbuat aniaya (kepada mereka). Dan tolong-menolonglah

kalian

dalam (mengerjakan) kebajikan dan takwa, dan jangan tolong-menolong dalam berbuat dosa dan pelanggaran. Dan bertakwalah kalian kepada Allah, sesungguhnya Allah amat berat siksaan-Nya".

Kebersyukuran yang sebenarnya harus memenuhi tiga unsur, yaitu syukur hati, syukur lisan, dan syukur perbuatan. Syukur dengan hati berarti meyakini dengan sepenuh hati bahwa segala nikmat yang diperoleh merupakan karunia Allah. Syukur lisan dilakukan dengan memuji Allah yang telah menganugerahkan berbagai nikmat, yakni dengan mengucapkan alhamdulillahirabbil 'alamin. Syukur perbuatan yang dimaksudkan disini ialah syukur dengan anggota badan, yaitu apa saja bentuk amalan kebajikan yang melibatkan anggota badan hendaklah dilaksanakan sebagai tanda telah bersyukur kepada Allah. Kondisi yang mendorongnya adalah kegembiraan dan sukacita terhadap nikmatnikmat Allah. Kegembiraan tersebut merupakan manifestasi syukur itu sendiri, karena hanya diperuntukkan bagi subtansiNya. Seseorang yang mempunyai sikap syukur merasa bahwa apa yang dimiliki saat ini semata-mata hanya titipan yang diberikan oleh Allah, baginya semua yang dimiliki hanyalah sebuah jalan untuk mendekatan diri kepada-Nya. Syukur yang dilandasi dengan hati, lisan dan perbuatan akan menciptakan rasa ikhlas dan ketulusan hati. Rasa ikhlas dan ketulusan hati ini yang akan mendorong seseorang untuk berbuat baik terhadap sesama. Salah satu perbuatan baik yang dimunculkan seseorang yang bersikap syukur ialah perilaku prososial.

Pada kenyataannya, fenomena perilaku prososial mahasiswa tidak selalu dapat ditemui dalam keseharian kehidupan di kampus. Contohnya saja membuang sampah sembarangan di area kampus, cuek saat ada teman terjatuh bahkan menertawakan teman tersebut, enggan berbagi tempat duduk di selasar kampus dikarenakan merasa terganggu ataupun sudah nyaman sehingga tidak mau bergeser dan menyerobot antrian di depan mesin ATM Bank. Yang sering terlihat adalah "pengondisian perilaku prososial" mahasiswa melalui kegiatan pengabdian 
kepada masyarakat, bakti sosial dan penugasan saat menjadi mahasiswa baru. Artinya, mahasiswa "harus dipaksa" untuk berperilaku prososial dengan harapan selama menjadi mahasiswa akan termotivasi untuk peduli kepada sesamanya.

Dengan penjelasan di atas, peneliti ingin melakukan penelitian hubungan kebersyukuran dengan perilaku prososial. Untuk itu peneliti menyebar dan membagikan kuesioner data awal kepada 30 responden yang dibagikan secara acak kepada mahasiswa di Prodi Ilmu Perpustakaan. Dari kuesioner tersebut diperoleh gambaran mahasiswa yang belum memenuhi aspek-aspek perilaku prososial dari teori Myer. Hal ini dilihat dari sebagian besar responden menyatakan tidak mau terlibat dengan masalah orang lain. Pernyataan pertama ini merujuk pada aspek empati. Kemudian sebagian besar responden menyatakan memperlakukan teman sesuai dengan kedekatan. Pernyataan kedua merujuk aspek mempercayai dunia yang adil. Lalu lebih dari $60 \%$ responden menyatakan kurang peduli terhadap orang yang membuang sampah di taman yang bersih. pernyataan ketiga ini merujuk pada tanggung jawab sosial.

Selanjutnya sebagian besar responden yang menyatakan tidak pernah menyesal dengan keputusan yang dibuat. Pernyataan keempat memperlihatkan tingkat locus of control internal. Terakhir lebih dari $83 \%$ responden menyatakan membuat keputusan didasarkan pada kepentingan dirinya pribadi. Pernyataan kelima berkaitan dengan egosentrisme rendah. Dengan demikian, dapat disimpulkan bahwa ada permasalahan pada perilaku prososial mahasiswa.

Berdasarkan gambaran fenomena yang dijelaskan di atas, maka peneliti tertarik untuk mengadakan penelitian mengenai "Hubungan Kebersyukuran dengan Perilaku Prososial Pada Mahasiswa Prodi Ilmu Perpustakaan UIN Imam Bonjol Padang”.

\section{Kebersyukuran}

Kata kebersyukuran berasal dari kata syakara - yasykuru - syukran, yang berarti terima kasih namun, tidak sekedar ucapan di bibir, "terima kasih". Bersyukur yang diperintahkan Alquran memiliki konsep yang dalam, terkait dengan konsep pengelolaan berbagai nikmat yang diberikan Allah SWT (Nawawi, 2014:100).

Kebersyukuran dalam bahasa Inggris disebut gratitude. Kata gratitude diambil dari akar Latin gratia, yang berarti kelembutan, kebaikan hati, atau berterima kasih. semua kata yang terbentuk dari akar Latin ini berhubungan dengan kebaikan, kedermawanan, pemberian, keindahan dari memberi dan menerima, atau mendapatkan sesuatu tanpa tujuan apapun (Emmons \& McCullough, 2003:4).

Peterson dan Seligman (2004:554) mendefinisikan bersyukur sebagai perasaan berterima kasih dan bahagia sebagai respon atas suatu pemberian, baik pemberian tersebut merupakan keuntungan yang nyata dari orang tertentu ataupun saat kedamaian yang diperoleh dari keindahan alamiah.

Berdasarkan pengertian-pengertian di atas, maka dapat disimpulkan bahwa bersyukur adalah ungkapan terima kasih atas hal-hal yang diperoleh selama hidup, baik dari Allah SWT, manusia, makhluk lain, dan alam semesta, yang mendorong individu untuk melakukan hal yang sama seperti yang ia dapatkan.

Syukur merupakan kualitas hati yang harus diraih dan dimiliki oleh setiap muslim. Dengan bersyukur kita akan swnantiasa diliputi rasa damai, tentram dan bahagia (Al-Bantanie, 2009). Keutamaankeutamaan yang bisa diperoleh dari bersyukur antara lain, yaitu (Ubaid, 2014):

a. Orang yang bersyukur diingat Allah SWT

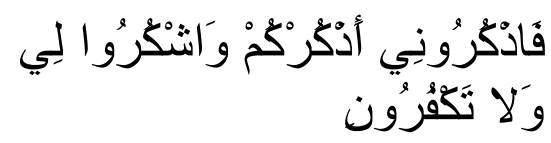


"Karena itu ingatlah kamu kepada-Ku niscaya aku ingat (pula) kepadamu, dan bersyukurlah kepada$K u$, dan janganlah kamu mengingkari (nikmat)-Ku." (Qs. al-Baqarah (2): 152)

Ayat diatas mengingatkan kita agar selalu ingat kepada Allah. Salah satu cara mengingat Allah adalah dengan senantiasa bersyukur kepadaNya. Jika kita ingat kepada Allah, Allah pun akan ingat kepada kita. Maksudnya Allah akan melipatkan rahmat dan karuniaNya kepada kita. Salah satu bentuk rahmat dan karunia Allah adalah mengeluarkan kita dari kesulitan dan menunjukkan jalan kemudahan.

b. Syukur Menghindarkan diri dari siksaan Allah SWT

Allah SWT mengaitkan syukur dengan keimanan dan mengatakan bahwa tidak ada alasan bagi-Nya untuk menyiksa makhluk bila ia bersyukur dan beriman. Hal ini terdapat dalam firman Allah SWT

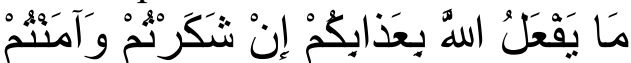

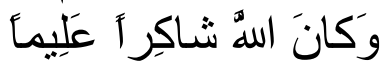
"Mengapa Allah akan menyiksa kalian, jika kalian bersyukur dan beriman? Dan Allah adalah Maha Mensyukuri lagi Maha Mengetahui". (QS. An-Nisa' (4): 147)

\section{c. Mendapat anugerah Allah SWT}

Allah SWT memberi tahu bahwa ahli syukur adalah orangorang yang secara khusus mendapatkan anugerah-Nya di antara hamba-hamba yang lain. Hal ini terdapat dalam firman Allah SWT

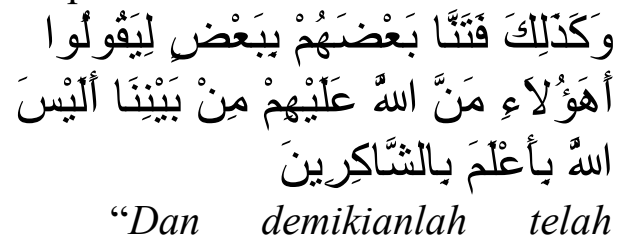

Kami uji sebagian mereka (orangorang kaya) dengan sebagian mereka (orang-orang

miskin), supaya (orang-orang kaya itu) berkata, "Orang-orang yang semacam inikah di antara kita yang diberi anugerah oleh Allah kepada mereka?" (Allah berfirman), "Tidakkah Allah lebih mengetahui tentang orang-orang yang bersyukur (kepada-Nya)?" (QS. Al-An'am (6): 530

d. Syukur menambah nikmat

Syukur akan menambah nikmat-nikmat yang belum ada, sehingga semakin bertambah. Dengan syukur pula, seseorang dapat mengikat nikmat-nikmat yang sudah ada dengan ikatan yang kuat, sehingga tidak mudah hilang. Hadist Nabi Muhammad SAW:

"Abu Zuhair Yahya bin Atharid Al-Quraisy dari ayahnya berkata bahwa Rasulullah SAW bersabda, "Tidaklah Allah memberi rezeki kepada seorang hamba kemudian ia bersyukur kecuali rezeki itu akan ditambah" (HR. Ibnu Abu Ad-Dunya), karena Allah berfirman, "Jika kamu bersyukur nisyaca Aku akan menambah (nikmat) kepadamu, tetapi jika kamu mengingkari (nikmat-Ku), maka azab-Ku sangat berat" (QS. Ibrahim (14): 7)

Komponen bersyukur(Listiyandini, Nathania, Syahniar, Sonia, dan Nadya (2015:478), yaitu:

1. Memiliki rasa apresiasi (sense of appreciation) terhadap orang lain ataupun Tuhan dan kehidupan. Komponen ini berasal dari komponen pertama Fitzgerald yaitu perasaan apresiasi yang hangat terhadap seseorang atau sesuatu. dan diperjelas oleh Watkins dengan karakteristik orang bersyukur kedua dan ketiga, yaitu mengapresiasi kontribusi orang lain terhadap kesejahteraan dirinya, dan memiliki kecenderungan untuk 
mengapresiasi kesenangan yang sederhana (simple pleasure).

2. Perasaan positif terhadap kehidupan yang dimiliki. Komponen ini berasal dari karakteristik orang bersyukur menurut Watkins, yaitu tidak merasa kekurangan dalam hidupnya atau dengan kata lain memiliki sense of abundance. Seseorang yang tidak merasa kekurangan akan memiliki perasaan positif dalam dirinya. Ia akan merasa berkecukupan terhadap apa yang dimilikinya, puas dengan kehidupan yang dijalaninya.

3. Kecenderungan untuk bertindak positif sebagai ekspresi dari perasaan positif dan apresiasi yang dimiliki. Komponen bersyukur yang kedua dan ketiga dari Fitzgerald, yaitu kehendak baik kepada seseorang atau sesuatu, serta kecenderungan untuk bertindak berdasarkan apresiasi dan kehendak baik yang dimilikinya, berkaitan dengan karakteristik terakhir dari individu yang bersyukur menurut Watkins, yaitu menyadari akan pentingnya mengekspresikan bersyukur. Ketiga hal ini menunjukkan bahwa bersyukur tidak hanya berkaitan dengan apresiasi terhadap apa yang diperoleh, tetapi juga terdapat unsur pengekspresian dari apresiasi dan perasaan yang dimiliki yang dapat diwujudkan dalam tindakan maupun kehendak baik.

\section{Perilaku Prososial}

Taylor, Peplau, L.A., \& Sears (2009) mengemukakan perilaku prososial mencakup katagori yang lebih luas karena meliputi segala bentuk tindakan yang dilakukan atau dirancang untuk menolong orang lain, tanpa memperdulikan motifmotif si penolong.

Perilaku prososial adalah suatu tindakan menolong yang menguntungkan orang lain tanpa harus menyediakan suatu keuntungan langsung kepada orang yang melakukan tindakan tersebut, dan mungkin bahkan melibatkan suatu resiko bagi orang yang menolong (Baron dan Byrne, 2005).

Perilaku prososial adalah suatu tindakan yang bertujuan untuk menolong orang lain dalam bentuk fisik maupun psikis, yang memberikan manfaat yang positif bagi orang yang dikenai tindakan itu tanpa mempedulikan motif si penolong atau dengan kata lain tidak memiliki keuntungan yang jelas bagi si penolong, tindakan itu dilakukan sesuai norma masyarakat yang berlaku serta bersifat nyata dan dapat diamati

\section{METODOLOGI PENELITIAN Metode Penelitian}

Jenis penelitian yang digunakan adalah penelitian korelasional dengan menggunakan pendekatan kuantitatif, yaitu pendekatan dengan hasil-hasil data berupa angka-angka yang membutuhkan analisis statistik. Pendekatan kuantitatif menekankan analisisnya pada data-data numerikal (angka) yang diolah dengan metoda statistika (Azwar, 2010: 5).

Penelitian korelasi merupakan penelitian yang bertujuan menyelidiki sejauh mana variasi pada satu atau lebih variabel lain, berdasarkan koefisien korelasi. Penelitian ini sangat cocok bila variabelvariabel yang terlibat sangat kompleks, pengukuran terhadap beberapa variabel dan saling-hubungan di antara variabel-variabel tersebut dapat dilakukan serentak dalam kondisi yang realistik (Azwar, 2010: 8).

\section{Populasi dan Sampel Penelitian}

Populasi dalam penelitian ini adalah mahasiswa prodi Ilmu Perpustakaan. Populasi dalam penelitian ini berjumlah 358 mahasiswa. Jumlah sampel ditentukan menggunakan rumus Slovin.

$$
\begin{aligned}
n & =358:\left\{1+358(0.05)^{2}\right\} \\
& =188.9
\end{aligned}
$$

Jadi, sampel penelitian apabila dibulatkan adalah 189 mahasiswa. Populasi dalam penelitian ini terbagi dalm 3 bagian, yaitu mahasiswa Prodi Ilmu Perpustakaan angkatan 2016, 2017, dan 2018. 
Tabel 2 Jumlah Sampel Penelitian

\begin{tabular}{ccccc}
\hline No. & Angkatan & Sampel & $\begin{array}{r}\text { Jumlah } \\
\text { Sampel }\end{array}$ \\
\hline 1 & 2016 & $\mathrm{n}=\frac{143}{358}$ & $\times 189$ & 76 \\
2 & 2017 & $\mathrm{n}=\frac{118}{358}$ & $\times 189$ & 62 \\
3 & 2018 & $\mathrm{n}=\frac{97}{358}$ & $\times 189$ & 51 \\
\hline \multicolumn{7}{c}{ Total } & $\mathbf{1 8 9}$ \\
\hline
\end{tabular}

HASIL PENELITIAN

\section{Kategori Kebersyukuran}

Tabel 3

Kategori Kebersyukuran

\begin{tabular}{cccc}
\hline Kategori & Interval & Frekuensi & Persen \\
\hline Rendah & $49-79$ & 82 & 43.4 \\
Tinggi & $79-95$ & 107 & 56.6 \\
\hline Total & & 189 & 100.0 \\
\hline
\end{tabular}

(Sumber: SPSS versi 16.0)

Berdasarkan tabel di atas, dapat disimpulkan bahwa kebersyukuran mahasiswa prodi Ilmu Perpustakaan cenderung tinggi. Berdasarkan data di atas, sebanyak 107 atau $56.6 \%$ dari 189 mahasiswa memiliki kemampuan cenderung tinggi dalam kategori kebersyukuran. Sementara sisanya yaitu sebanyak 82 atau $43.4 \%$ dari 189 responden memiliki kebersyukuran yang cenderung rendah, atau kebersyukurannya masih kurang. Jadi, dapat disimpulkan bahwa tingkat kebersyukuran pada mahasiswa prodi Ilmu Perpustakaan cenderung tinggi. Artinya, mahasiswa prodi Ilmu Perpustakaan pada umumnya memiliki rasa apresiasi (sense of appreciation) terhadap orang lain ataupun Tuhan dan kehidupan. Selain itu, mereka tidak merasa kekurangan akan memiliki perasaan positif dalam diri mereka. Mereka akan merasa berkecukupan terhadap apa yang dimilikinya, serta puas dengan kehidupan yang dijalaninya. Kemudian mahasiswa prodi Ilmu Perpustakaan cenderung untuk bertindak positif sebagai ekspresi dari perasaan positif dan apresiasi yang dimiliki.
Kategori Perilaku Prososial

Tabel 4

Kategori Perilaku Prososial

\begin{tabular}{cccc} 
Kategori & Interval & Frekuensi & Persen \\
\hline Rendah & $107-157$ & 90 & 47.6 \\
Tinggi & $157-192$ & 99 & 52.4 \\
\hline Total & 189 & 100.0 \\
\hline Sumber: SPSS versi 16.0) \\
Berdasarkan tabel di atas, dapat
\end{tabular}

disimpulkan bahwa perilaku prososial mahasiswa prodi Ilmu Perpustakaan cenderung tinggi. Berdasarkan data di atas, sebanyak 99 atau 52.4\% dari 189 mahasiswa memiliki kemampuan cenderung tinggi dalam kategori perilaku prososial. Sementara sisanya yaitu sebanyak 90 atau $47.6 \%$ dari 189 responden memiliki perilaku prososial yang cenderung rendah, atau perilaku prososialnya masih kurang.

Dari besarnya persentase perilaku prososial pada tabel tersebut, menunjukkan bahwa mahasiswa prodi Ilmu Perpustakaan lebih dominan memiliki perilaku prososial pada kategori tinggi. Artinya, mahasiswa prodi Ilmu Perpustakaan memiliki tanggung jawab, bersifat sosial, selalu menyesuaikan diri, toleran, dapat mengontrol diri, dan termotivasi untuk membuat kesan yang baik. Lalu mahasiswa prodi Ilmu Perpustakaan yakin akan adanya keadilan di dunia ini. Selain itu, mereka memiliki rasa tanggung jawab sosial. Mereka juga mampu mengontrol dirinya secara internal. Kemudian, mahasiswa prodi Ilmu Perpustakaan memiliki keegoisan yang rendah. Dia lebih mementingkan orang lain dari pada dirinya sendiri, bukanlah selfabsorbed dan kompetitif.

\section{Korelasi}

Penelitian ini adalah penelitian korelasi yang melibatkan dua variabel untuk diuji apakah terdapat hubungan yang signifikan antar keduanya, sehingga uji hipotesis dilakukan dengan teknik korelasi product moment menggunakan bantuan aplikasi statistik SPSS versi 17.0 for windows dengan dua acuan pengambilan 
keputusan. Apabila nilai Sig. $<0,05$ (kecil dari 0,05) maka terdapat korelasi yang signifikan, apabila nilai Sig. $>0,05$ (besar dari 0,05) maka tidak adanya korelasi (hubungan) yang signifikan. Hasil analisis SPSS dapat dilihat pada tabel berikut.

Tabel 5

Hasil Analisis Korelasi Pearson

\begin{tabular}{cccc}
\hline Variabel & N & r & Sig. \\
\hline $\begin{array}{c}\text { Kebersyukuran - } \\
\text { Perilaku Prososial }\end{array}$ & 189 & 0.486 & 0.001 \\
\hline
\end{tabular}

(Sumber: SPSS versi 16.0)

Hasil analisis pada tabel 5 menunjukkan bahwa nilai koefisien pearson correlation kebersyukuran dan perilaku prososial sebesar 0,486. Yang menjadi acuan pengujian hipotesis adalah nilai signifikansi (Sig.) yaitu 0,001 , dengan nilai Sig. $<0,05$ (kecil dari 0,05) maka terdapat hubungan antara kebersyukuran dengan perilaku prososial, artinya hipotesis terbukti. Hubungannya memiliki arah positif, yaitu apabila kebersyukuran tinggi maka perilaku prososial cenderung tinggi.

\section{Pembahasan}

Dari penelitian yang telah dilakukan, kebersyukuran memiliki hubungan dengan perilaku prososial. Diperoleh hasil jika kebersyukuran memiliki hubungan yang signifikan dan memiliki taraf hubungan yang sedang dengan perilaku prososial. Hal ini sesuai dengan nilai signifikansi pada analisis korelasi yaitu 0,000 , pada proses pengambilan keputusan karena $0,000<0,05$ (lebih kecil dari 0,05) maka hipotesis diterima yaitu terdapat hubungan.

Untuk menentukan derajat hubungan kedua variabel dapat ditentukan melalui nilai koefisien korelasi. Menurut Priyatno (2014: 112) hubungan kedua variabel semakin erat jika mendekati nilai 1 (untuk korelasi positif) dan mendekati -1 (untuk korelasi negatif). Dalam penelitian ini hasil nilai korelasi yang didapat bernilai negatif. Berikut tabel kriteria koefisien korelasi yang dapat digunakan sebagai acuan.
Tabel 6

Interpretasi Koefisien Korelasi

\begin{tabular}{cc}
\hline Interval Koefisien & $\begin{array}{c}\text { Tingkat } \\
\text { Hubungan }\end{array}$ \\
\hline $0,00-0,199$ & Sangat Rendah \\
$0,20-0,399$ & Rendah \\
$0,40-0,599$ & Sedang \\
$0,60-0,799$ & Kuat \\
$0,80-1,000$ & Sangat Kuat \\
\hline \multicolumn{2}{c}{ (Sugiyono, 2014: 192) }
\end{tabular}

Berdasarkan tabel interpretasi di atas, dapat disimpulkan bahwa kebersyukuran dengan perilaku prososial memiliki hubungan yang cenderung sedang. Karena nilai koefisien korelasi pearson dari hasil analisis tabel SPSS adalah 0,486 yang bernilai positif. Artinya semakin tinggi kebersyukuran maka semakin tinggi perilaku prososial pada mahasiswa.

Berdasarkan data kategorisasi variabel, kemampuan kebersyukuran mahasiswa cenderung tinggi dan perilaku prososialnya juga cenderung tinggi. Artinya sikap mahasiswa prodi ilmu Perpustakaan cenderung tinggi untuk menolong orang lain. Hal ini sejalan dengan kebersyukuran mahasiswa yang cenderung tinggi. Meskipun beberapa mahasiswa masih belum memiliki kebersyukuran dan perilaku prososial yang tinggi.

Mahasiswa prodi Ilmu Perpustakaan UIN Imam Bonjol Padang memiliki memiliki rasa apresiasi (sense of appreciation) terhadap orang lain ataupun Tuhan dan kehidupan. Selain itu, mereka tidak merasa kekurangan akan memiliki perasaan positif dalam diri mereka. Mereka akan merasa berkecukupan terhadap apa yang dimilikinya, serta puas dengan kehidupan yang dijalaninya. Kemudian mahasiswa cenderung untuk bertindak positif sebagai ekspresi dari perasaan positif dan apresiasi yang dimiliki yang bisa diwujudkan melalui perilaku prososial. Mahasiswa ini juga memiliki bersifat sosial, selalu menyesuaikan diri, toleran, dapat mengontrol diri, dan termotivasi untuk membuat kesan yang baik. Lalu mereka yakin akan adanya keadilan di dunia ini. 
Selain itu, mereka memiliki rasa tanggung jawab sosial. Kemudian, mahasiswa prodi Ilmu Perpustakaan memiliki keegoisan yang rendah. Mereka lebih mementingkan orang lain dari pada dirinya sendiri, bukanlah selfabsorbed dan kompetitif.

Riset yang dilakukan oleh Williamson dan Clark (dalam Wicaksono dan Susilawati, 2016: 204) menunjukkan bahwa mahasiswa yang bisa memberi pertolongan kepada orang lain merasa lebih senang dan tenang dibanding mahasiswa yang tidak mendapat kesempatan untuk menolong. Mahasiswa yang dapat memberi pertolongan merasakan dirinya menjadi lebih baik seperti merasa lebih sabar, tidak egois, dan dapat diandalkan. Evaluasi positif yang diperoleh setelah melakukan perilaku prososial seperti yang dirasakan mahasiswa diyakini akan meningkatkan psychological well-being mahasiswa.

\section{Kesimpulan}

Berdasarkan hasil penelitian yang diperoleh pada pembahasan sebelumnya, maka kesimpulan yang diperoleh adalah sebagai berikut:

1. Tingkat literasi media pada mahasiswa pengguna instagram di UIN Imam Bonjol Padang cenderung tinggi, yaitu sebanyak 52 atau $54,7 \%$.

2. Jumlah tingkat sikap terhadap penyebaran hoax pada mahasiswa pengguna Instagram di UIN Imam Bonjol Padang cenderung rendah (positif), yaitu sebanyak 61 atau 64,2\%. Artinya Mahasiswa UIN Imam Bonjol Padang cenderung menolak penyebaran hoax.

3. Terdapat hubungan (korelasi) antara literasi media dengan sikap terhadap penyebaran hoax. Keduanya memiliki arah korelasi yang negatif, hal ini menunjukkan bahwa semakin tinggi literasi media maka sikap terhadap penyebaran hoax akan cenderung positif (rendah). Kedua variabel memiliki tingkat hubungan yang sedang (cukup), dengan nilai koefisien korelasi sebesar $-4,446$.

\section{DAFTAR KEPUSTAKAAN}

Azwar, S. (2010). Metode Penelitian. Yogyakarta : Pustaka Pelajar

Baron, R.A. \& Byrne, D. (2005). Psikologi Sosial Jilid Dua Ed Kesepuluh. Jakarta: Erlangga

Cahyono, Y.B. (2016). Persepsi Tentang Metode Service Learning, Konsep Diri dan Perilaku Prososial Mahasiswa. Persona, Jurnal Psikologi Indonesia, Volume 5, No. 02, 115-125

Chaplin, J.P. (2006). Kamus Lengkap Psikologi. Jakarta: PT RajaGrafindo Persada

Emmons, R.A. \& McCullough, M.E. (2004). The Psychology of Gratitude. New York: Oxford University Press

Listiyandini, R.A., Nathania, A., Syahniar, D., Sonia, L., \& Nadya, R. (2015). Mengukur Rasa Syukur: Pengembangan Model Awal Skala Bersyukur Versi Indonesia. Jurnal Psikologi Ulayat, Volume 2. No. 2, 473-496

Nawawi, R.S. (2014). Kepribadian Qur'ani. Jakarta: Amzah 
Peterson, C., \& Seligman, M.E.P. (2004). Character Strength and Virtues: A Handbook \& Classification. New York: Oxford University Press.

Priyatno, D. (2014). SPSS 22: Pengolahan Data Terpraktis. Yogyakarta: Andi.

Renata, S. \& Parmitasari, D.L.N. (2016). Perilaku Prososial pada Mahasiswa ditinjau dari Jenis Kelamin dan Tipe Kepribadian. Journal Unika, Volume 15, No. 1, 24-39

Sugiyono. (2014). Metode Penelitian Kuantitatif Kualitatif dan $R \& D$. Bandung: Alfabeta

Taylor, S.E., Peplau, L.A., \& Sears, D.O. (2009). Psikologi Sosial Ed. Kedua Belas Cetakan kedua. Jakarta: Kencana

Yulianti. (2017). Identifikasi Perilaku Prososial Siswa Kelas VII SMP Jaya Manggala. Skripsi (tidak dipublikasikan). Tanggerang Banten: Sekolah Tinggi Agama Budha Negeri Sriwijaya

Sears, D.O, Freedman, J.L, \& Peplau, L.A. (2001). Psikologi Sosial Jilid Dua Ed. Kelima. Jakarta: Erlangga

Ubaid, U.A. (2014). Sabar dan Syukur: Gerbang Kebahagiaan di Dunia dan di Akhirat, Cetakan kedua. Jakarta: Amzah

Wicaksono, M.L.H. \& Susilawati, L.K.P.A. (2016). Hubungan Rasa Syukur dan Perilaku Prososial Terhadap Psychological Well-Being Pada Remaja Akhir Anggota Islamic Medical Activists Fakultas Kedokteran Universitas Udayana. Journal Udayana, Volume 3, No. 2, 196-208 